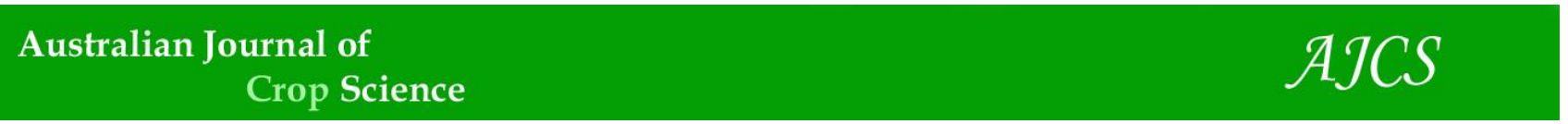

AJCS 14(09):1420-1426 (2020)

ISSN:1835-2707

doi: 10.21475/ajcs.20.14.09.p2420

\title{
Safflower genotypes affected by nitrogen fertilization in subtropical conditions
}

\author{
Paulo de Lima Bueno, Reginaldo Ferreira Santos, Doglas Bassegio, Cristiano Fernando Lewandoski, \\ Claudia Luiza Maziero, Diane Maschio de Souza, Samuel Nelson Melegari de Souza, Caroline Beal Montiel
}

Universidade Estadual do Oeste do Paraná, UNIOESTE, CEP 85819-1 30, Cascavel, PR, Brazil

\author{
*Corresponding authors: Paulo_bueno@hotmail.com
}

\begin{abstract}
Nitrogen fertilization is one of the main management systems that affects safflower (Carthamus tinctorius) production. However, the response of safflower to nitrogen fertilization may vary depending on the genotype and growing conditions. The objective of this study was to evaluate the influence of nitrogen fertilization on yield components, oil content, and protein content of safflower genotypes in subtropical conditions. Two experiments were performed to evaluate the effect of nitrogen fertilization $(0$ and $160 \mathrm{~kg}$ $\mathrm{ha}^{-1}$ ) on six safflower genotypes. The experiment was designed in randomized blocks, in a $2 \times 6$ factorial design, with six repetitions. The height of the plants, yield, and oil and protein contents were determined 170 and 160 days after emergence in 2017 and 2018 , respectively. The oil content and protein content of safflower genotypes were affected by nitrogen fertilization, but this effect varied depending on the genotype. Genotype 4 dominated with a grain yield of $1088 \mathrm{~kg} \mathrm{ha}^{-1}$ and an oil yield of $215 \mathrm{~kg}^{-1}$. Nitrogen fertilization increased the grain yield, oil content, and protein content; thus, it is appropriate for the cultivation of safflower off-season in autumn-winter in subtropical conditions. Safflower genotype 4 could be a promising oilseed crop for southern Brazil when fertilized with $100 \mathrm{~kg} \mathrm{ha}^{-1}$ of $\mathrm{N}$.
\end{abstract}

Keywords: Carthamus tinctorius L.; oilseeds; industrial crops.

Abbreviations: DAE_days after emergence; SOM_Soil organic matter; BS_Base saturation.

\section{Introduction}

There is great need to adopt plants that have industrial potential and that are also tolerant to abiotic stresses. Characteristic of tropical climates, safflower (Carthamus tinctorius L.) is a candidate species that can be grown in autumn-winter in Brazil (Sarto et al., 2018). It is an oilseed crop with potential for cultivation in dry areas (Lovelli et al., 2007; Santos et al., 2017). Safflower seeds have a considerable high-quality oil content (35-45\%), which can be used for human consumption and industrial use. Safflower oil has high levels of oleic acid (30\%) and linoleic acid (70\%), and can be used as raw material for biodiesel production (Ilkılıç et al., 2011). In Brazil, safflower can be used for the second harvest (autumn-winter harvest). This crop is still little known and, therefore, the performance of this species requires investigation. Due to the risk of irregular rainfall, farmers use little fertilizer and rarely perform nitrogen topdressing (Santos et al., 2019). However, nitrogen is fundamentally important for the growth and development of safflower, and is one of the most important safflower management techniques (Dordas and Sioulas, 2009). One of the most efficient ways for safflower to develop in tropical conditions is through the proper application of fertilizers. Nevertheless, it is necessary to elucidate the appropriate amount of fertilizer required.

Several studies have declared safflower to be responsive to nitrogen topdressing (Dordas and Sioulas, 2008; Dordas and Sioulas, 2009; Elfadl et al., 2009; Soleimani, 2010; Shahrokh; niaa and Sepaskhah, 2016; Shahrokhniaa and Sepaskhah, 2017; Santos et al., 2018). However, studies of the nitrogen fertilization of safflower have presented conflicting results. This discrepancy may be related to residual $\mathrm{N}$ in the soil, different safflower genotypes, and variable climatic conditions (Dordas and Sioulas, 2009). Yau and Ryan (2010) revealed that safflower did not respond to the application of $\mathrm{N}$, which may have been due to its deep root system capable of absorbing N. Different genotypes exhibited differences in the accumulation and partitioning of $\mathrm{N}$ into different plant organs (Papakosta and Gagianas, 1991). Thus, the accumulation of dry matter can be affected by genotype (Koutroubas et al., 2004). The impact of $\mathrm{N}$ fertilization on safflower has not been extensively studied in Brazil. In this sense, the introduction of $\mathrm{N}$-efficient genotypes may be important for safflower harvesting in subtropical conditions. Currently, there is insufficient information on the interaction between genotype and nitrogen with oil content and protein content. The response of safflower to nitrogen fertilization may vary according to genotype. The objective of this study was to evaluate the influence of nitrogen fertilization on yield components, oil content, and protein content of different North American safflower genotypes in subtropical conditions.

Results

Plant height

The plant height was significantly affected $(P<0.01)$ by the interaction of the genotype and nitrogen factors in 2017 
(Table 1). The application of nitrogen increased the plant height of genotype 4 with values of $114.4 \mathrm{~cm}$. The interaction of the factors demonstrated that the height of genotype 5 plants was reduced by nitrogen application (Table 2; Figure 1). In 2018 the application of nitrogen increased the plant height of all safflower genotype (Table 2). However, in 2018 the plant height of safflower genotypes 2 and 4 were similar $(85.3 \mathrm{~cm})$. The average plant height was $84 \mathrm{~cm}$ in 2017 and $76 \mathrm{~cm}$ in 2018.

\section{Yield}

Grain yield was not affected $(P>0.01)$ by the interaction of genotype and nitrogen in either year (Table 1 and 2). Thus, the effects of genotype and nitrogen are presented separately. The application of nitrogen led to significantly higher $(P<0.05)$ grain yields in both 2017 and 2018. In 2017, genotype 4 , which had a yield of $1088 \mathrm{~kg} \mathrm{ha}^{-1}$, dominated over genotypes 1 and 6, which had yields of 701 and $573 \mathrm{~kg}$ $\mathrm{ha}^{-1}$, respectively. In 2018, although genotype 4 appeared to have a higher grain yield $\left(864 \mathrm{~kg} \mathrm{ha}^{-1}\right)$, there was no significant variation between the genotypes $(P>0.05)$.

\section{Oil content}

The oil content was significantly affected $(P<0.01)$ by the interaction of genotype and nitrogen in both years (Table 2 and 3). The highest oil contents were observed for genotypes 2 and 6 in both years, with a maximum of $24 \%$ in 2017 (Figure 2A). Nitrogen fertilization increased the oil content of genotypes 5 and 6 in both years. However, the oil content of genotype 4 was reduced with nitrogen application. Meanwhile, the oil contents of genotypes 1 and 2 were not affected by nitrogen fertilization (Figure 2A and B).

\section{Protein content}

The protein content was significantly influenced $(P<0.01)$ by the interaction of genotype and nitrogen in both years (Table 2 and 3). Genotype 1 was notable for its protein content, benefiting from the application of nitrogen in both years (Figure $3 \mathrm{~A}$ and $\mathrm{B}$ ). The protein values for genotype 1 were 14 and $17 \%$ in the years 2017 and 2018, respectively (Figure $3 \mathrm{~A}$ and $\mathrm{B}$ ). The average protein content of all genotypes was $11.7 \%$ in 2017 and 8.4\% in 2018 (Table 1 and 2).

\section{Oil yield and protein yield}

Oil yield was not affected $(P>0.05)$ by the interaction of genotype and nitrogen, so the effects of the factors are discussed separately (Table 1 and 2). In 2017, genotype 4 had the highest oil yield of $215 \mathrm{~kg} \mathrm{ha}^{-1}$, compared to genotypes 1, 5, and 6, which had values of 89, 123, and 126 $\mathrm{kg} \mathrm{ha}^{-1}$, respectively (Table 1 and 2 ).

As was the case with the grain yield, the oil yield was not significantly affected $(P>0.05)$ by different genotypes in 2018. The oil yield ranged from 58 to $122 \mathrm{~kg} \mathrm{ha}^{-1}$ in 2018 . However, the application of nitrogen significantly increased $(P<0.05)$ the oil yield of genotypes (Table 2 ).

The protein yield was significantly affected $(P<0.05)$ by the interaction of genotype and nitrogen only in 2017 (Table 1). Nitrogen increased the protein yield in genotype 1 from 42 to $152 \mathrm{~kg} \mathrm{ha}^{-1}$ (Figure 4). In 2018, the application of nitrogen increased the overall protein yield from 37 to $78 \mathrm{~kg} \mathrm{ha}^{-1}$ (Table 2).

\section{Discussion}

Nitrogen fertilization increased the plant height of safflower (Table 1; Figure 1), which corroborates previous findings (Abbadi et al., 2008). Nitrogen is one of the most important nutrients for agricultural production, as it affects the production of dry matter, influencing the development and maintenance of the leaf area, as well as the photosynthetic efficiency (Shahrokhniaa and Sepaskhah, 2017). Under N deficiency, growth is inhibited, and the root to shoot ratio is decreased (Steer and Harrigan, 1986). The application of 46 $\mathrm{kg} \mathrm{ha}^{-1}$ of nitrogen has been shown to increase safflower height by $18 \%$ compared to unfertilized plants (Shahrokhniaa and Sepaskhah, 2017).

The grain yield benefited from the application of nitrogen, with an increase of 34\% in 2017 and 43\% in 2018 (Table 1 and 2). Dordas and Sioulas (2008) reported that nitrogen fertilization at a rate of $150 \mathrm{~kg}$ of $\mathrm{N} \mathrm{ha}^{-1}$ increased the production of safflower grains by $19 \%$. Safflower grain yield can be expressed using several components. The components of the direct yield are the plant population, the number of heads per plant, the number of seeds per head, and the weight of seeds (Gilbert and Tucker, 1967). The relative importance of each component is affected by many factors, including genetic factors. High variation in grain yield was detected for several genotypes (923-3391 kg ha-1) (Koutroubas et al., 2008). The maximum yield was $1088 \mathrm{~kg}$ $\mathrm{ha}^{-1}$, which was observed in genotype 4 . This yield was lower than the yield of Brazilian genotypes (3820-4532 $\mathrm{kg} \mathrm{ha}^{-1}$ ) of safflower grown in Southern Brazil (Sampaio et al., 2016; Zanão Júnior et al., 2017). The oil yield of the genotypes varied significantly only in the first year, with values from 89 to $215 \mathrm{~kg} \mathrm{ha}^{-1}$. Thus, the grain yields of the North American genotypes tested in the South Brazil were lower than previously reported. Referring to the work of Mazieiro et al. (2019), it can be suggested that this may have been due to the lack of adaptation of the genotypes to the subtropical conditions.

The oil content can be adjusted by applying nitrogen and by choosing the genotype (Figure $2 \mathrm{~A}$ and $\mathrm{B}$ ). The content of safflower oil is not generally affected by the application of $\mathrm{N}$ (Elfadl et al., 2009). The results of the present study revealed that some genotypes were affected by nitrogen application, but this effect was not consistent. The oil content ranged from 8 to $24 \%$. Mazieiro et al. (2019) noted a variation of 12 to $23 \%$ in North American safflower genotypes. Zanão Júnior et al. (2017) observed a variation of 23 to $29 \%$. Santos et al. (2018) reported a variation of 24 to $30 \%$ for a Brazilian genotype. The oil content is strongly dependent on the genotype (Hang and Evans, 1985). It is evident that the nitrogen application had a greater effect on the yield of safflower grains than on the oil content. A higher oil yield was observed due to the application of nitrogen, with an increase of 34 and 48\% in the years 2017 and 2018, respectively. These results corroborate the findings of Dordas and Sioulas (2008), who observed no effect on oil content. However, the effect on grain yield compensated for the reduction in oil content.

The protein content was affected by the interaction of the genotype and nitrogen (Figure $3 \mathrm{~A}$ and $\mathrm{B}$ ). The protein concentration is an important property of safflower seeds due to the use of the seeds in animal feed (Shahrokhniaa 
Table 1. Plant height, grain yield, oil content, and protein of safflower genotypes with nitrogen fertilization in 2017.

\begin{tabular}{|c|c|c|c|c|c|c|}
\hline Treatments & Plant height $(\mathrm{cm})$ & $\begin{array}{l}\text { Grain Yield } \\
\left(\mathrm{kg} \mathrm{ha}^{-1}\right)\end{array}$ & $\begin{array}{l}\text { Oil content } \\
(\%)\end{array}$ & $\begin{array}{l}\text { Protein } \\
(\%)\end{array}$ & $\begin{array}{l}\text { Oil yield (kg } \\
\mathrm{ha}^{-1} \text { ) }\end{array}$ & $\begin{array}{l}\text { Protein yield ( } \mathrm{kg} \\
\left.\mathrm{ha}^{-1}\right)\end{array}$ \\
\hline \multicolumn{7}{|l|}{ Genotype } \\
\hline 1 & $85.2 \mathrm{bc}$ & $701 b$ & $12.8 \mathrm{e}$ & $12.6 \mathrm{ab}$ & $89 c$ & $97 a b$ \\
\hline 2 & 83.1 bc & $793 a b$ & $23.6 \mathrm{a}$ & $13.0 \mathrm{a}$ & $186 a b$ & $104 a b$ \\
\hline 3 & 86.9 bc & $882 a b$ & $18.9 \mathrm{c}$ & $12.0 \mathrm{abc}$ & $168 a b$ & $107 a b$ \\
\hline 4 & $107.7 \mathrm{a}$ & $1088 \mathrm{a}$ & $19.9 \mathrm{bc}$ & $11.5 \mathrm{c}$ & $215 \mathrm{a}$ & $126 \mathrm{a}$ \\
\hline 6 & $89.1 \mathrm{~b}$ & $573 b$ & $21.9 \mathrm{ab}$ & $11.7 \mathrm{bc}$ & $126 \mathrm{bc}$ & $67 \mathrm{~b}$ \\
\hline \multicolumn{7}{|c|}{ Nitrogen $\left(\mathrm{kg} \mathrm{ha}^{-1}\right)$} \\
\hline 0 & 87.1 & $690 \mathrm{~b}$ & 18.6 & $10.9 \mathrm{~b}$ & $130 \mathrm{~b}$ & $76 \mathrm{~b}$ \\
\hline 100 & 89.0 & 925 a & 19.1 & $12.4 \mathrm{a}$ & $175 \mathrm{a}$ & $114 \mathrm{a}$ \\
\hline \multicolumn{7}{|c|}{ ANOVA ( $P$ values) } \\
\hline Genotype (G) & $<0.000$ & 0.005 & $<0.000$ & $<0.000$ & $<0.000$ & 0.0039 \\
\hline Nitrogen $(N)$ & 0.399 & 0.002 & 0.2432 & $<0.000$ & 0.0042 & $<0.000$ \\
\hline
\end{tabular}

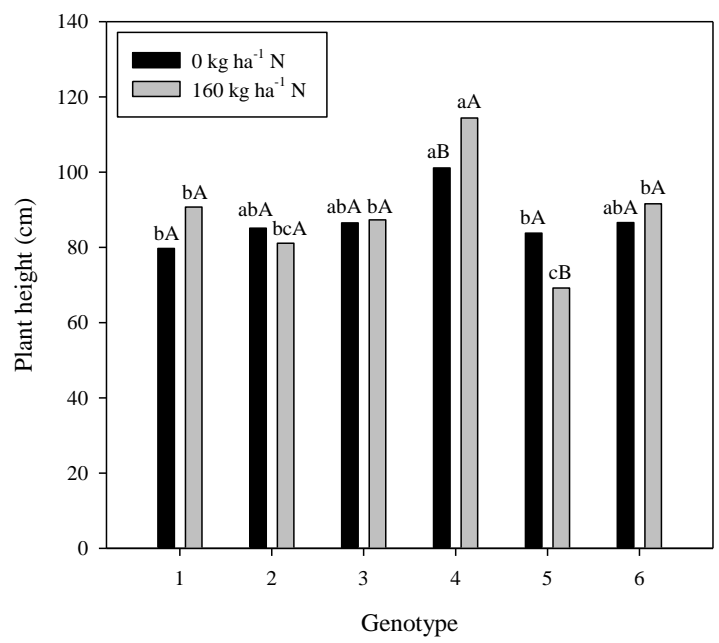

Fig 1. Plant height in 2017. Values followed by a different lowercase letter are significant difference between genotypes same nitrogen fertilization. Values followed by a different capital letter are significant difference among nitrogen fertilization under same genotype (Tukey test, $\mathrm{P}<0.05$ ).

Table 2. Plant height, grain yield, oil content, and protein of safflower genotypes with nitrogen fertilization in 2018.

\begin{tabular}{|c|c|c|c|c|c|c|c|}
\hline Treatments & $\begin{array}{l}\text { Plant } \\
(\mathrm{cm})\end{array}$ & height & $\begin{array}{l}\text { Grain yield } \\
\left(\mathrm{kg} \mathrm{ha}^{-1}\right)\end{array}$ & $\begin{array}{l}\text { Oil content } \\
(\%)\end{array}$ & $\begin{array}{l}\text { Protein } \\
(\%)\end{array}$ & $\begin{array}{l}\text { Oil yield (kg } \\
\mathrm{ha}^{-1} \text { ) }\end{array}$ & $\begin{array}{l}\text { Protein yield (kg } \\
\mathrm{ha}^{-1} \text { ) }\end{array}$ \\
\hline \multicolumn{8}{|l|}{ Genotype } \\
\hline 1 & $70.8 \mathrm{bc}$ & & 622 & $9.0 \mathrm{~d}$ & $9.7 \mathrm{a}$ & 58 & 67 \\
\hline 2 & $85.3 \mathrm{a}$ & & 698 & $17.1 \mathrm{a}$ & $9.2 a b$ & 120 & 67 \\
\hline 3 & $76.3 \mathrm{~b}$ & & 607 & $13.6 \mathrm{~b}$ & $8.8 \mathrm{bc}$ & 84 & 55 \\
\hline 4 & $85.3 \mathrm{a}$ & & 864 & $14.1 \mathrm{~b}$ & $8.2 \mathrm{c}$ & 122 & 73 \\
\hline 5 & $72.6 \mathrm{bc}$ & & 654 & $11.7 \mathrm{c}$ & $6.5 d$ & 80 & 42 \\
\hline 6 & $65.8 \mathrm{c}$ & & 472 & $15.9 \mathrm{a}$ & $8.5 \mathrm{bc}$ & 78 & 43 \\
\hline \multicolumn{8}{|c|}{ Nitrogen $\left(\mathrm{kg} \mathrm{ha}^{-1}\right)$} \\
\hline 0 & $72.9 \mathrm{~b}$ & & $536 \mathrm{~b}$ & $11.9 \mathrm{~b}$ & $6.9 \mathrm{~b}$ & $64 \mathrm{~b}$ & $37 \mathrm{~b}$ \\
\hline 100 & $79.2 \mathrm{a}$ & & $770 \mathrm{a}$ & $15.3 \mathrm{a}$ & $10.0 \mathrm{a}$ & $117 \mathrm{a}$ & $78 \mathrm{a}$ \\
\hline \multicolumn{8}{|c|}{ ANOVA ( $P$ values) } \\
\hline Genotype (G) & $<0.000$ & & 0.2564 & $<0.000$ & $<0.000$ & 0.0548 & 0.2093 \\
\hline Nitrogen $(\mathrm{N})$ & 0.003 & & 0.0144 & $<0.000$ & $<0.000$ & 0.0005 & $<0.000$ \\
\hline $\mathrm{G} \times \mathrm{N}$ & 0.090 & & 0.9944 & 0.0002 & $<0.000$ & 0.9631 & 0.3387 \\
\hline
\end{tabular}


Table 3. Soil chemical characteristics in the experimental areas before initiating the experiment.

\begin{tabular}{|c|c|c|c|c|c|c|c|c|}
\hline Year & $\mathrm{pH}\left(\mathrm{CaCl}_{2}\right)$ & SOMt & $P($ resin) & $\mathrm{H}+\mathrm{Al}$ & $\begin{array}{l}\text { Exchangeable } \\
\mathrm{K}\end{array}$ & $\begin{array}{l}\text { Exchangeable } \\
\mathrm{Ca}\end{array}$ & $\begin{array}{l}\text { Exchangeable } \\
\text { Mg }\end{array}$ & BS $\ddagger$ \\
\hline & & $\mathrm{g} \mathrm{dm}^{-3}$ & $\mathrm{mg} \mathrm{dm}^{-3}$ & \multicolumn{4}{|c|}{$--------\mathrm{cmol}_{\mathrm{c}} \mathrm{dm}^{-3}--------$} & $\%$ \\
\hline 2017 & 4.4 & 50 & 2.8 & 9.7 & 0.37 & 4.1 & 1.5 & 40 \\
\hline 2018 & 5.0 & 32 & 9.4 & 6.2 & 0.33 & 5.2 & 2.9 & 58 \\
\hline
\end{tabular}

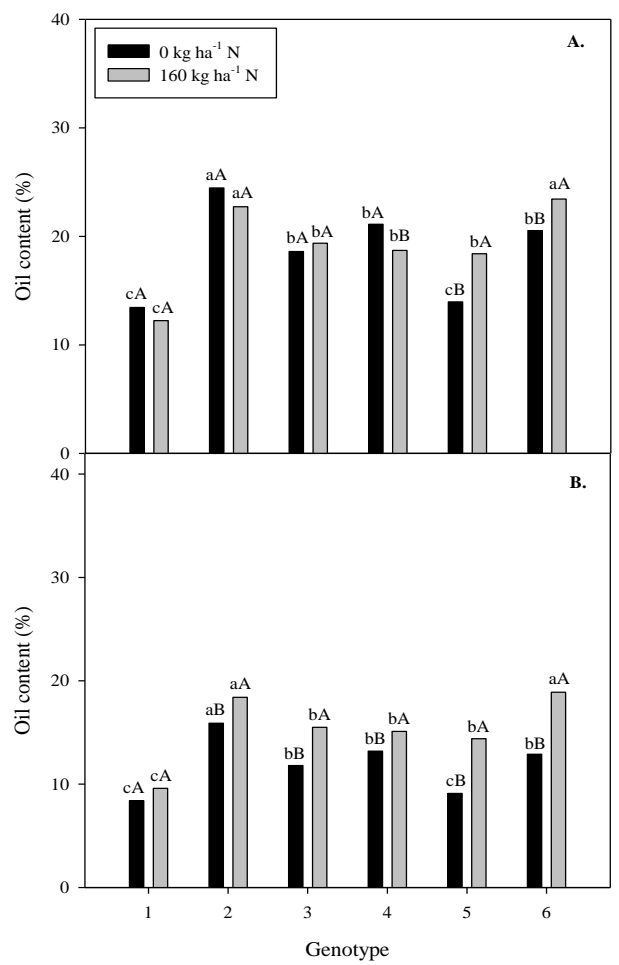

Fig 2. Oil content in 2017 (A) and 2018 (B). Values followed by a different lowercase letter are significant difference between genotypes same nitrogen fertilization. Values followed by a different capital letter are significant difference among nitrogen fertilization under same genotype (Tukey test, $\mathrm{P}<0.05$ ).

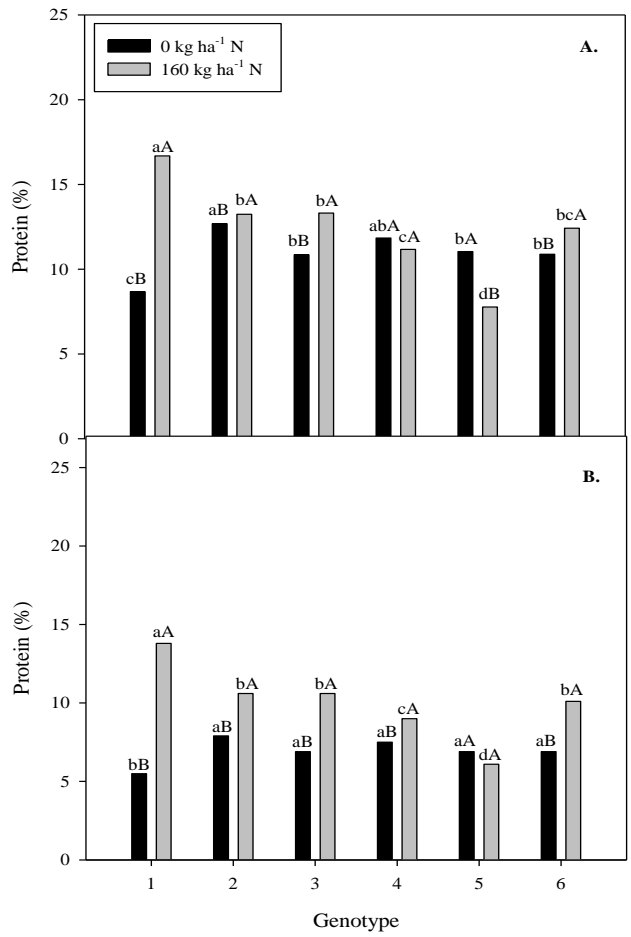

Fig 3. Protein in 2017 (A) and 2018 (B). Values followed by a different lowercase letter are significant difference between genotypes same nitrogen fertilization. Values followed by a different capital letter are significant difference among nitrogen fertilization under same genotype (Tukey test, $\mathrm{P}<0.05$ ) 


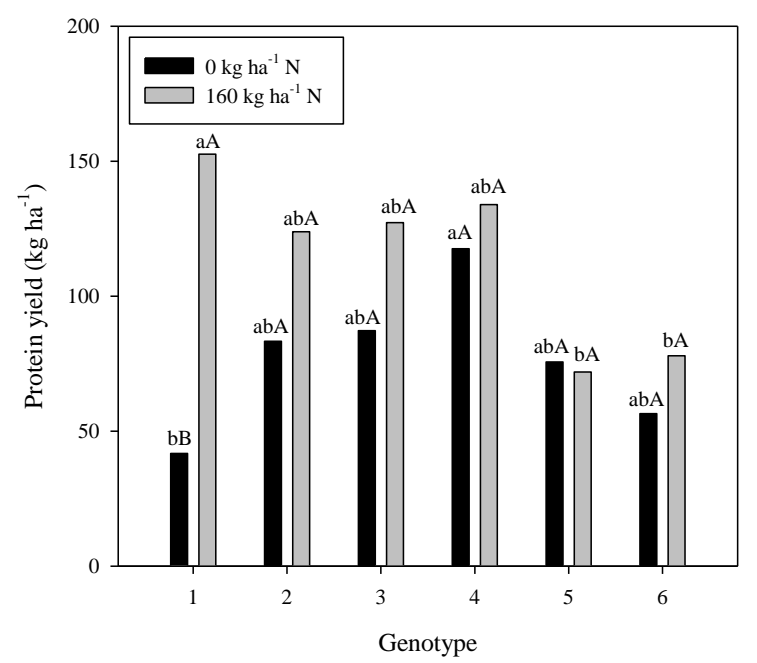

Fig 4. Protein yield in 2017. Values followed by a different lowercase letter are significant difference between genotypes same nitrogen fertilization. Values followed by a different capital letter are significant difference among nitrogen fertilization under same genotype (Tukey test, $\mathrm{P}<0.05$ ).

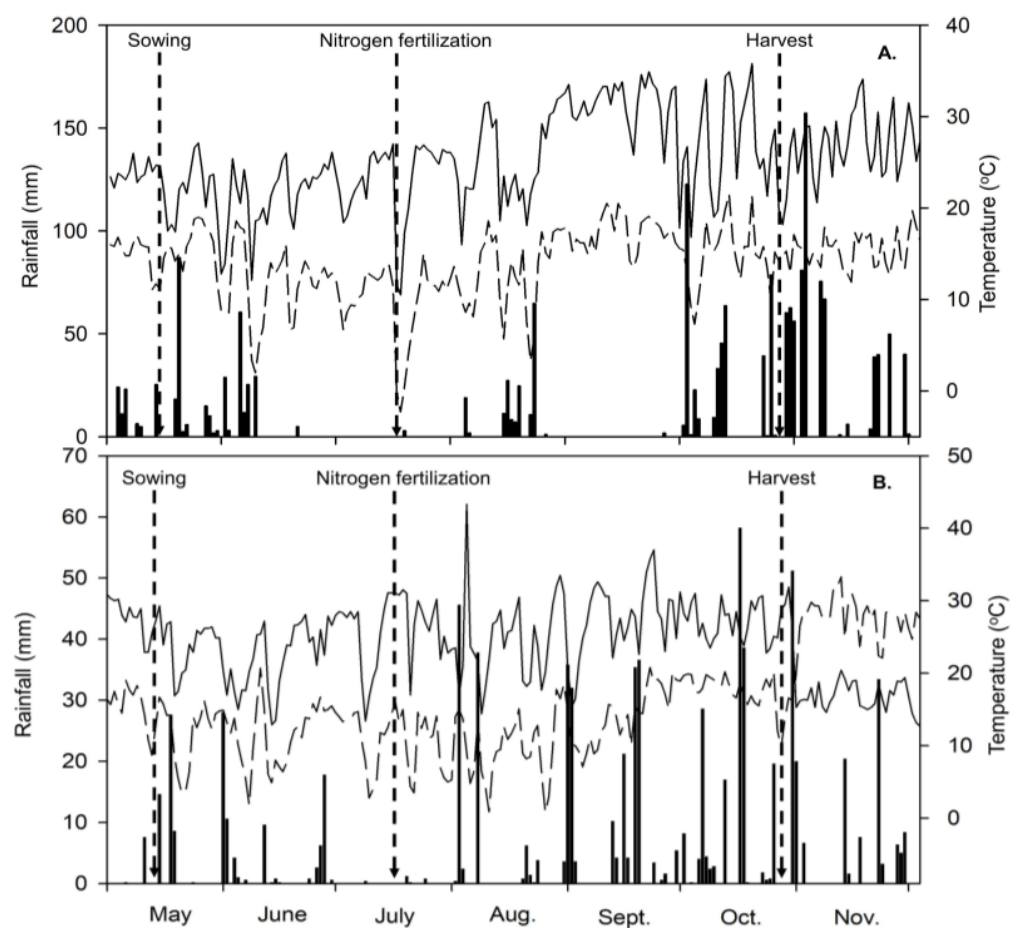

Fig 5. Behavior of meteorological variables of precipitation and mean temperature during safflower cultivation Cascavel, PR, Brazil, in 2017 and 2018.

and Sepaskhah, 2017). Nitrogen fertilization in mulch was effective in increasing the protein content of safflower, which is widely accepted in the literature and is in line with the findings of Dordas and Sioulas (2008) and Shahrokhniaa and Sepaskhah (2017). Higher protein values have been obtained with nitrogen fertilization due to the higher nitrogen accumulation and grain yield. The protein content has been shown to increase by $40 \%$ compared to control (Dordas and Sioula, 2008). The variation in protein content was 5 to $17 \%$ in the present study. Mazieiro et al. (2019) observed a protein content variation of 8 to $17 \%$ for North American safflower genotypes. Due to the strong effect of nitrogen application on protein content, it is evident that protein yield was substantially increased by nitrogen application, at an average of 66\% in 2017 and 47\% in 2018.

\section{Materials and methods}

\section{Plant materials}

The safflower genotypes used were originally from the North American company.

\section{Location and climatic conditions}

Two experiments were performed in Cascavel, Paraná, Brazil. In 2017, the experiment was conducted at Fundetec 
(Foundation for Scientific and Technological Development; $25^{\circ} 00^{\prime} 39^{\prime \prime} \mathrm{S}, 53^{\circ} 17^{\prime} 22^{\prime \prime} \mathrm{W}$, altitude of 785 meters). In 2018, the experiment was conducted at UNIOESTE (Western Parana State University; $24^{\circ} 59^{\prime} 21.2^{\prime \prime}$ S $53^{\circ} 26^{\prime} 59.6^{\prime \prime} \mathrm{W}$, altitude of $781 \mathrm{~m}$ ). According to the Köppen classification, the climate of the sites is subtropical Cfa type, without a defined dry season. The average temperature of the hottest month is higher than $22^{\circ} \mathrm{C}$ and the average temperature in the coldest month is lower than $18^{\circ} \mathrm{C}$, with hot summers and infrequent frosts in winter. The behavior of the meteorological variables during the experiment is shown in Figure 5.

The soil in the experimental area was classified as Rhodic Acrudox (Soil Survey Staff, 2014). Before starting the experiment, the chemical characteristics of the soil were determined (0-20 cm; Table 3) according to the methods of Embrapa et al. (2009).

\section{Experimental setup}

Before implantation, glyphosate [isopropylamine salt of $\mathrm{N}$ (phosphonomethyl) glycine] was applied $(1.44 \mathrm{~g}$ acidequivalent $\mathrm{ha}^{-1}$ ). Ten days after sowing, the pre-emergence herbicide, s-metolachlor, was applied $\left(1 \mathrm{~kg} \mathrm{ha}^{-1}\right)$.

The genotypes were sown on May 12, 2017 and May 2, 2018. The sowing was performed mechanically, using a seeder fertilizer machine, regulated to 32 seeds per meter. At the time of sowing, base fertilization was performed with $300 \mathrm{~kg} \mathrm{ha}^{-1}$ of fertilizer 08-20-20 (N-P2O5-K2O). For seed treatment, Imidacloprid was applied at $90 \mathrm{~g}$ a.i. per $100 \mathrm{~kg}$ of seed and Thiodicarb was applied at $30 \mathrm{~g}$ a.i. per $100 \mathrm{~kg}$ of seed.

\section{Treatments and experimental design}

The experimental design was in randomized blocks, in a $2 \times 6$ factorial design, with six repetitions. Six genotypes of safflower $(1,2,3,4,5$, and 6$)$ and two rates of nitrogen application ( 0 and $160 \mathrm{~kg} \mathrm{ha}^{-1}$ ) were used. Nitrogen topdressing was performed 50 days after emergence (DAE), using encapsulated urea ( $46 \% \mathrm{~N})$. Each plot consisted of five lines measuring $4 \mathrm{~m}$ in length, with $0.45 \mathrm{~m}$ spacing between lines.

\section{Traits evaluated}

The harvest occurred 170 and 160 days after the emergence of the plants in the 2017 and 2018 seasons, respectively. The height of the plants was determined by measuring the distance between the ground level and the apex of the plant with a graduated tape. Six random plants were measured within each plot. The plants were collected from $1 \mathrm{~m}^{2}$ of each plot, before threshing and manual cleaning of the seeds were performed. The values were expressed in $\mathrm{kg} \mathrm{ha}^{-1}$. The moisture content was determined using the gravimetric method by drying a sub-sample for 24 $\mathrm{h}$ at $105^{\circ} \mathrm{C}$ and correcting for $12 \%$. For the evaluation of the oil content, the extraction was performed using a Soxhlet extractor (IAL, 2008) under laboratory conditions using petroleum ether solvent. The extraction was performed with $2 \mathrm{~g}$ of ground seeds. The protein content was determined using the Bradford method (1976). The oil and protein yields were determined by multiplying the oil and protein content by the grain yield.

\section{Statistical analysis}

The statistical analysis was based on the analysis of variance and comparison of averages using the Tukey test with a significance threshold of $5 \%(P<0.05)$. Statistical analyses were performed using the SISVAR 5.6 statistical software.

\section{Conclusions}

The oil content and protein content of safflower genotypes were affected by nitrogen fertilization, but this effect varied depending on the genotype. Nitrogen fertilization increased the grain yield, oil content, and protein content, and it is thus recommended for growing safflower off-season in autumn-winter. Nitrogen fertilization is important for safflower due to the severe rates of decomposition and nitrogen dynamics in the soil under subtropical conditions.

\section{Acknowledgments}

The authors thank CAPES (Coordenação de Aperfeiçoamento de Pessoal de Nível Superior) for financial support. The authors thank FUNDETEC (Fundação para o Desenvolvimento Científico e Tecnológico).

\section{References}

Abadi J, Gerendas J (2011) Effects of phosphorous supply on growth, yield and yield components of safflower and sunflower. J Plant Nutr Soil Sc. 34:1769-1787.

Bradford MM (1976) A rapid and sensitive method for the quantification of microgram quantities of protein utilizing the principle of protein-dye binding. Anal. Biochem. 72:248254.

Dordas CA, Sioulas C (2008) Safflower yeld, chiofophill content, photosynthesis and water use efficiency response to nitrogen fertilization under raifed conditions. Ind Crops Prod. 27:75-85.

Dordas CA, Sioulas C (2009) Dry matter and nitrogen accumulation, partitioning, and retranslocation in safflower (Carthamus tinctorius L.) as affected by nitrogen fertilization. Field Crops Res. 110:35-43.

Dordas CA, Lithourgidis AS, Matsi TH, Barbayiannis N (2008) Application ofliquid cattle manure and inorganic fertilizers affect dry matter, nitrogen accu-mulation, and partitioning in maize. Nutr. Cycl. Agroecosys. 80:283-296.

Embrapa - Empresa brasileira de pesquisa agropecuária. Centro Nacional de Pesquisa de Solos. Manual de análises químicas de solos, plantas e fertilizantes. 2. ed. Brasília: Informação Tecnológica, 2009. 628 p.

Elfadl E, Reinbrecht C, Frick C, Claupein W (2009) Optimization of nitrogen rate and seed density for safflower (Carthamus tinctorius L.) production under low-input farming conditions in temperate climate. Field Crops Res. 114:2-13.

Gilbert NW, Tucker TC (1967) Growth, yield, and yield components of saffloweras affected by source, rate and time of application of nitrogen. Agron J. 59:54-55.

Hang AN, Evans DW (1985) Deficit sprinkler irrigation of sunflower and safflower. Agron J. 77:588-592.

Ilkılıç C, Aydın S, Behcet R, Aydin H (2011) Biodiesel from safflower oil and its application in a diesel engine. Fuel Process Technol. 92:356-362. 
Instituto Adolfo Lutz (2008) Métodos físico-químicos para análise de alimentos. 4a ed. 1ạed. digital. São Paulo: Secretaria de Estado da Saúde.

Koutroubas SD, Papakosta DK, Doitsinis A (2004) Cultivar and seasonal effects

on the contribution of pre-anthesis assimilates to safflower yield. Field Crops Res. 90:263-274.

Koutroubas SD, Papakosta DK, Doitsinis A (2009) Phenotypic variation in physiological determinants of yield in spring sown safflower under Mediterranean conditions.

Field Crops Res. 112:199-204.

Lovelli S, Perniola M, Ferrara A, Di Tommaso T (2007) Yield response factor to water (Ky) and water use efficiency of Carthamus tinctorius L. and Solanum melongena L. Agr Water Manage. 92:73-80.

Maziero CL, Santos RF, Bassegio D, Lewandoski CF, Lima Bueno P, Silva TRB, Rosseto RE (2019) Initial growth and agronomic performance of some important North American safflower cultivars. Aust J Crop Sci. 13:726-731.

Papakosta DK, Gagianas AA (1991) Nitrogen and dry matter accumulation,remobilization, and losses for Mediterranean wheat during grain filling. Agron. J. 83:864-870.

Soleimani R (2010) Variability of grain and oil yield in spring safflower as affected by nitrogen application. J Plant Nutr. 33:1744-1750.

Sampaio MC, Santos RF, Bassegio D, Vasconselos ES, Silva MA, Secco D, Silva TRB (2016) Fertilizer improves seed and oil yield of safflower under tropical conditions. Ind Crops Prod. 94:589-595.

Santos RF, Bassegio D, Silva MA (2017) Yield and production components of safflower genotypes affected by irrigation at phenological stages. Agr Water Manage. 186:66-74.
Santos RF, Bassegio D, Sartori MMP, Zanotto MD, Silva MA (2018) Safflower (Carthamus tinctorius L.) yield as affected by nitrogen fertilization and different water regimes. Acta Agron. 67:264-269.

Santos RF, Bassegio D, Silva MA, Klar AE, Silva, AAF, Silva, TRB (2018) Irrigated safflower at different phenological stages of Brazilian southeast dry season. Irriga 23:493-504.

Sarto MVM, Bassegio D, Rosolem CA, Sarto JR (2018) Safflower root and shoot growth affected by soil compaction. Bragantia 77:348-355.

Steer T, Harrigan EKS (1986) Rates of nitrogen supply during different devel-opmental stages affect yield components of safflower (Carthamus tinctorius L.). Field Crops Res. 14:221231.

Shahrokhnia MH, Sepaskhah AR (2017) Physiologic and agronomic traits in safflower under various irrigation strategies, planting methods and nitrogen fertilization. Ind Crops Prod. 95:126-139.

Shahrokhnia MH, Sepaskhah AR (2016) Effects of irrigation strategies, planting methods and nitrogen fertilization on yield, water and nitrogen efficiencies of safflower. Agr Water Manage. 172:18-30.

Yau SK, Ryan J (2010) Response of rainfed safflower to nitrogen fertilization under Mediterranean conditions. Ind Crops Prod. 32:318-323.

Zanão Júnior LA, Paschoal TS, Pereira N, Araújo PM, Secco D, Santos RF, Prior M (2017) Seed yield, oil content and accumulation of macronutrients in safflower (Carthamus tinctorius L.) genotypes in subtropical region. Aust J Crop Sci. 11:1254-1260. 